\title{
Speleothems as indicators of wet and dry periods
}

\author{
Ian John Fairchild ${ }^{1}$ and Emily Anne McMillan ${ }^{2}$
}

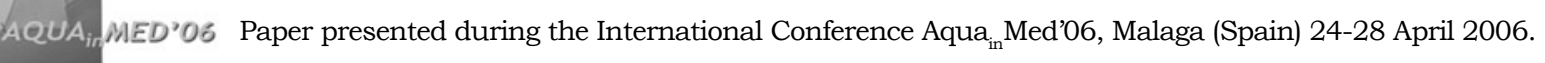

\begin{abstract}
:
Fairchild I.J. and McMillan E.A. 2007. Speleothems as indicators of wet and dry periods. International Journal of Speleology, 36 (2), 69-74. Bologna (Italy). ISSN 0392-6672.

Calcareous speleothems provide a record of dripwater composition which in turn is a function of climatic conditions. The historical focus of speleothem palaeoclimate studies has been on the derivation of palaeotemperatures through oxygen isotope studies. However, it is now realized that water availability is a more generally important control on their characteristics. Growth rate and growth morphology in principle should give rise to recognizable changes at low flow. However, accidental plumbing effects during aquifer evolution, can also lead to variations in water supply and it is not easy to distinguish these effects. In areas where there is a strong amount effect on the $\delta^{18} \mathrm{O}$ composition of atmospheric precipitation, the speleothem $\delta^{18} \mathrm{O}$ composition can be a direct (and inverse) function of rainfall. High-resolution methods are now available to distinguish the composition and relative abundance of winter and summer precipitation in speleothems which formed from drips of seasonally-varying composition. Two seasonallyvarying processes can be responsible for significant geochemical effects during the year. Seasonal (normally summer) dryness enhances $\mathrm{CO}_{2}$-degassing which leads to elevated $\delta^{13} \mathrm{C}, \mathrm{Mg} / \mathrm{Ca}$ and $\mathrm{Sr} / \mathrm{Ca}$ in dripwaters, characteristics which are transferred to speleothems. The same effects can arise by enhanced degassing at low $\mathrm{PCO}_{2}$. High-resolution analysis can distinguish the seasonal processes and, where conducted at several time intervals, allows a more confident interpretation of longer-term records.
\end{abstract}

Keywords: speleothems; palaeohydrology; stable isotopes; trace elements

Received 30 November 2006; Revised 3 February 2007; Accepted 28 February 2007

\section{INTRODUCTION}

Calcareous speleothems, cave deposits such as stalactites, stalagmites and flowstones are phenomena which are generated by a complex set of processes in part dependent on climate. During the late 20th century, the main focus of research was on $\delta^{18} \mathrm{O}$ records in speleothems as palaeotemperature indicators. However, even where the results of this approach can be calibrated in the instrumental period (e.g. Mangini et al., 2005), there are discrepancies with other palaeoclimate indicators, and it now appears that shifts in meteorological patterns over time need to be considered. Such changing patterns are also likely to be reflected in changing rainfall amount and indeed much attention is currently being

1 School of Geography, Earth and Environmental Sciences, University of Birmingham, Edgbaston, Birmingham B15 2TT i.j.fairchild@bham.ac.uk

2 Geotechnics Ltd, The Geotechnical Centre, Block 1 Unit 8, Duckburn Business Park, Dunblane FK15 OEW given to properties of speleothems that depend on the availability of dripwater, and hence relate to the amount of water infiltrating into the karst system on different timescales. These variations will be critical for speleothems growing in sub-humid to semi-arid climates such as those found in the Mediterranean region. The functional relationships with cave system behaviour offer a number of lines of evidence that can be compared, particularly to distinguish genuine climatic changes, from local modifications to the plumbing of the karstic network, unconnected with climate.

\section{AMOUNT EFFECT ON $\boldsymbol{\delta}^{18} \mathrm{O}$}

A number of the more spectacular palaeoclimatic results from speleothems in recent years have been derived from the study of $\delta^{18} \mathrm{O}$ variations in regions where this is a strong inverse function of rainfall amount. The amount effect on $\delta^{18} \mathrm{O}$ is known to be the dominant pattern in the tropics, in areas dominated by strongly convective monsoonal rainfall (particularly monsoonal climates), and in certain semi-arid areas, 
where weak rains are prone to partial re-evaporation in the atmosphere. Study of the composition of individual events may reveal a control by rainfall amount that is hidden by an apparent temperature effect based on the more common monthly timescale of analysis (Treble et al., 2005a). The work of Ayalon et al. (1999) and BarMatthews et al. (2003) established rainfall amount as a major control of $\delta^{18} \mathrm{O}$ in rainfall in Israel today, and applied this knowledge to provide a quantitative interpretation of Holocene speleothems. In Oman and southern and eastern China, there have been a series of studies illustrating a clear inverse dependence of $\delta^{18} \mathrm{O}$ on the intensity of monsoonal rainfall which, is strongly correlated with summer insolation. These patterns have been demonstrated over timescales from tens of years to hundreds of years to hundreds of thousands of years (e.g. Fleitmann et al., 2003, 2007; Wang et al., 2005; Johnson et al., 2006). On these timescales, the atmospheric effects are dominant and the detailed behaviour of the karstic system is subordinate. However, in climatically less-sensitive regions, and for more precise and short-term studies, more knowledge of the cave environment is needed.

\section{KARSTIC PLUMBING AND SPELEOTHEM DRIPS}

Consideration of the cave environment in the context of its karstic aquifer must take account of the complex, triple-porosity systems present in the aquifer. Karstic conduits are the most variable flow system, and they tend to feed only the most variable and fast-flowing sources of water for speleothems, tending to flow only after heavy rainfall. Karstic fractures are the primary medium for fast delivery of water to dripstone speleothems after rainfall. The remaining slowflowing water is derived by seepage from the karstic matrix. Water flowpaths can be complex and are not directly determinable, but where the geology is sufficiently simple, it is possible to attempt to model the relationships between atmospheric precipitation and drip discharge (Fairchild et al., 2006a). The model shown in outline in Figure 1 has been shown to be capable of producing a reasonable match to the estimated variations of water infiltration in response to rainfall at a site with a horizontally-bedded Jurassic aquifer, with various model tunings to fit dripwaters of a wide variety of coefficients of variation of discharge. The fits to hydrochemistry are much more variable; conservative mixing is shown to be an inadequate approximation to aquifer behaviour, whilst prior calcite precipitation (see section 5.3) proves to be an essential component of the model.

\section{DRIP RATE AND GROWTH RATE RESPONSE}

Our knowledge of the response of speleothem growth rate to various factors in the cave stems largely from the detailed modelling of Dreybrodt $(1988,1999)$ and associates. Under conditions where the cave air $\mathrm{PCO}_{2}$ is set at atmospheric levels, the supersaturation of the fluid, and hence the growth rate, depends largely on the Ca content of the water, which is a strong function of the maximum $\mathrm{PCO}_{2}$ that it has encountered when

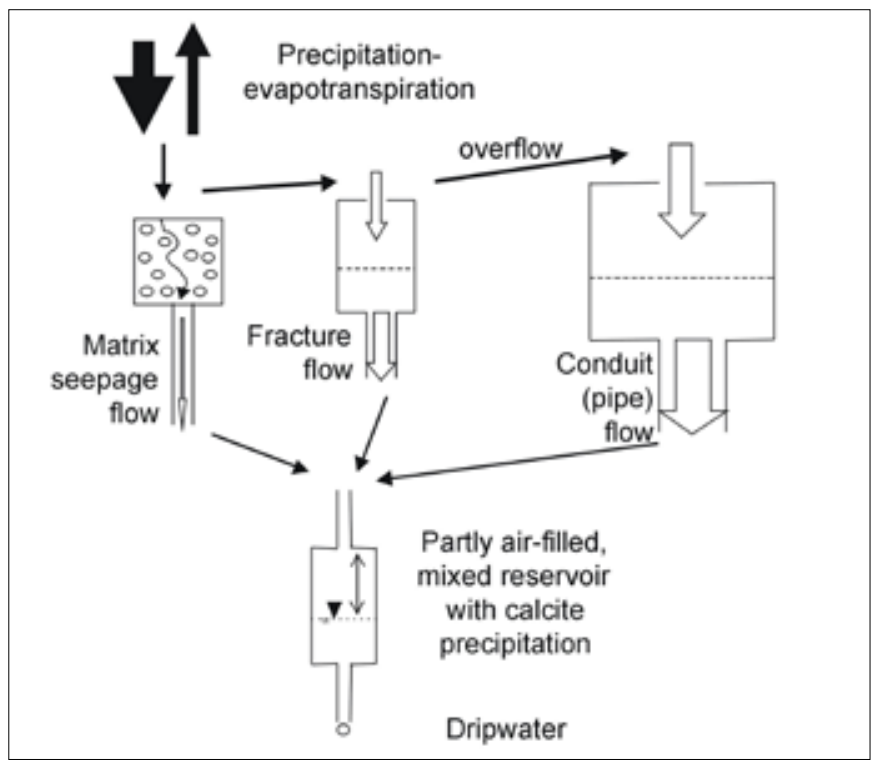

Fig. 1. System model of controls on the composition in karstic dripwaters, based on the modelling study of Fairchild et al. (2006a) at Brown's Folly Mine, UK; the system form is the simplest possible to explain the observed changes in hydrology and hydrogeochemistry. Drips are fed by a mixture of water from different flowpaths and, often the matrix seepage reservoir, which dominates at low flow, is enriched in a trace element such as Mg or Sr compared with other flowpaths.

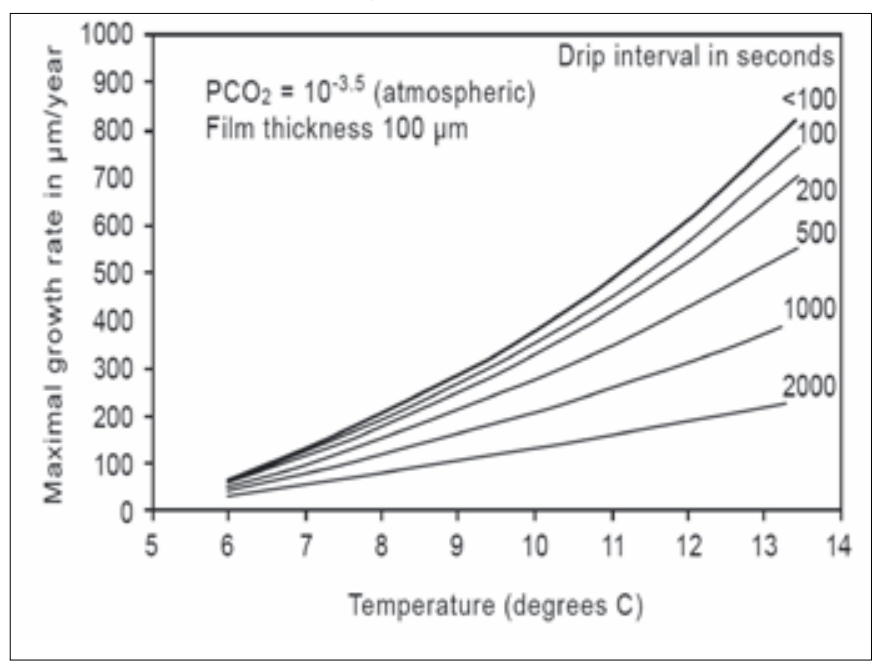

Fig. 2. Modelled maximal growth rates of speleothems under a stagnant fluid layer by combining the predictions of the Dreybrodt growth model with the field data on Ca concentration of dripwaters in Genty et al. (2001). Factors such as prior calcite precipitation are known to have reduced $\mathrm{Ca}$ (Fairchild et al., 2000; 2006a) at certain of the sites of Genty et al. (2001), so their linear regression line is modified to rise from $50 \mathrm{mg} /$ litre at $6^{\circ} \mathrm{C}$ to $160 \mathrm{mg} /$ litre at $14^{\circ} \mathrm{C}$.

in contact with carbonate rock - typically in the soil zone, or in the upper epikarst above the cave. In turn this maximum $\mathrm{PCO}_{2}$ is a function of temperature, although this is subject to sufficient water availability. The general growth rate can thus be related to environmental temperature (Fig. 2, upper line). Under conditions where ion supply from dripwaters is slow (drip interval $>100$ seconds), this becomes the limiting factor on speleothem growth and under these conditions, varying driprate (lower lines on Fig. 2) could be the main factor responsible for variations in growth rate with time. Under these conditions, growth rate directly reflects water infiltration which, given a 


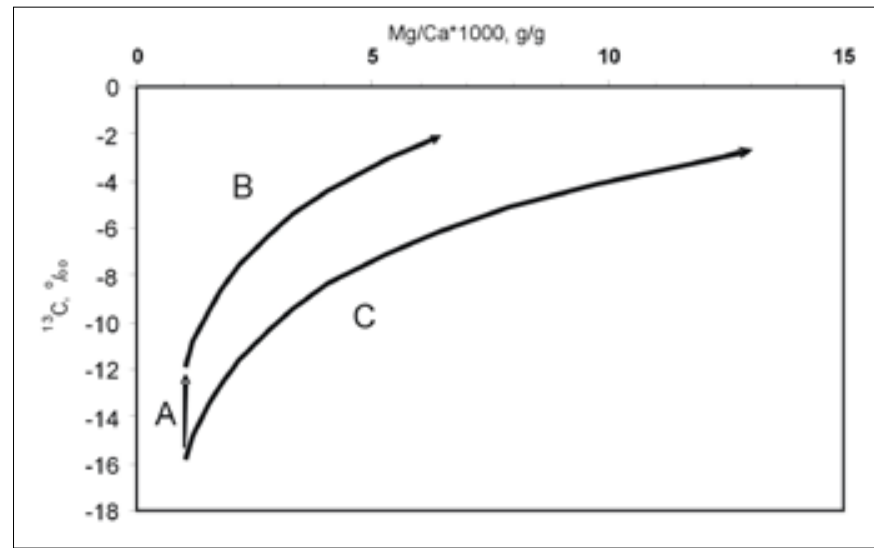

Fig. 3. Pathways of evolution of $\square 13 \mathrm{C}$ and $\mathrm{Mg} / \mathrm{Ca}$ in speleothems forming from solutions at steady supersaturation marked by a balance of $\mathrm{CO}_{2}$-degassing and calcite precipitation. Line A represents degassing only followed in line $B$ by a balance of degassing and calcite precipitation; line $C$ is like line $B$, but without the initial degassing step. Initial water composition based on dripwaters from Crag Cave feeding the stalagmite CC3 (McDermott et al., 1999; Tooth \& Fairchild, 2003; McDermott et al., 2005): Ca 105 mg/L, Mg 6.7 Mg/L and total dissolved inorganic carbon $359 \mathrm{mg} / \mathrm{litre}$, and assuming a partition coefficient for $\mathrm{Mg}$ in calcite of 0.016 .

normal (positive) relationship between drip discharge and infiltrating rainwater, then relates to atmospheric precipitation and hence climate.

Dreybrodt (1999) has also modelled the changing width of stalagmites in response to driprate, where a positive variation is expected. Overall a reduced width leading to a hiatus in which insoluble matter accumulates, or an irregular corrosion surface may develop, during an extended period of below-average rainfall leading to temporary cessation of dripping.

\section{HYDROGEOCHEMICAL RESPONSES TO LOW FLOWS}

The hydrochemical response of an aquifer is inherently more complex than that of the hydrology, but non-linear effects on both can occur. Since the epikarst is a diphasic air-water system (Mangin 1975, Genty and Deflandre, 1998), a key phenomenon is the increasing penetration of cave air into the plumbing system leading to localized cessation or diversion of flow as air pockets develop. This can accentuate the tendency for dry periods to tap different parts of the aquifer, and also accelerates the process of degassing $\mathrm{CO}_{2}$ from the cave water excess to that in equilibrium with the $\mathrm{PCO}_{2}$ of cave air (Fairchild et al., 2006a, b).

\section{Seepage from low-permeability aquifer omponents}

At low flows, drainage from fracture-fed parts of the aquifer is minimized, and the proportion of flow from low-permeability parts of the aquifer with long mean water residence time increases. Prolonged contact times tend to increase the dissolution of slowly-reacting minerals such as dolomite, leading to enrichment of $\mathrm{Mg}$ in the flow. In Mesozoic aquifers (Baker et al., 2000; Fairchild et al., 2006a), a Sr enrichment has also been noted that can be related to the preservation of Sr-rich aragonite in more shaley parts of the limestone aquifer.

\section{Causes of prior calcite precipitation}

The driver for speleothem precipitation is the $\mathrm{CO}_{2}$-difference between soil/upper epikarst and the cave system. Calcite precipitation as soon as water encounters lowered $\mathrm{PCO}_{2}$ in air circulating in the cave may occur significantly up-flow of the point where dripwater is sampled and/or is precipitating speleothem calcite. Prior calcite precipitation refers to this up-flow process, as shown schematically in Figure 1. Prior calcite precipitation will tend to be enhanced by two processes: seasonal falls in $\mathrm{CO}_{2}$ in the cave air, and seasonally low water flows, leading to more extensive penetration of air into the aquifer. Patterns both of winter depletion in cave air $\mathrm{PCO}_{2}$ (e.g. Bourges et al. 2001) and summer depletion (e.g. Hoyos et al., 1998) can occur. The controlling factors include potentially increased winter ventilation (Spötl et al., 2005) sometimes related to thermo-convective instability (Bourges et al., 2006), water-filling of $\mathrm{CO}_{2}-$ bearing fissures from the epikarst, and temperature and rainfall controls on soil $\mathrm{PCO}_{2}$ (Fairchild et al., 2006c). Seasonally low flows leading to enhanced degassing into air will tend to be in summer in Mediterranean climates. This may work either together with or in the opposite sense to the $\mathrm{PCO}_{2}$ effect. Much more cave monitoring is needed to understand more fully these phenomena.

\section{Consequences of degassing and prior calcite precipitation}

Degassing (line A in Fig. 3) has the effect of removing $\mathrm{CO}_{2}$ whose $\mathrm{C}$ is isotopically light, hence enriching the residual solution in $13 \mathrm{C}$. The solution changes little in terms of its total dissolved inorganic carbon, but increases in saturation. Then further evolution of the solution is related to the coupling of further $\mathrm{CO}_{2}$ loss to the precipitation of $\mathrm{CaCO} 3$, which produces $\mathrm{CO}_{2}$ as a by-product. Lines $\mathrm{B}$ and $\mathrm{C}$ in Figure 3 are examples to illustrate the progressive change in $813 \mathrm{C}$ composition of dripwaters and speleothems as this process proceeds (see Spötl et al., 2005 for a more detailed example of carbon isotope modelling). The $\mathrm{Mg}$ content of the speleothem progressively increases because the $\mathrm{Mg} / \mathrm{Ca}$ of the calcite is much lower than the $\mathrm{Mg} / \mathrm{Ca}$ of the solution from which it forms (the ratio of the two is the partition coefficient) and hence the solution becomes progressively enriched in $\mathrm{Mg} / \mathrm{Ca}$. Another hallmark of this process is a simultaneous enrichment in both $\mathrm{Sr}$ and $\mathrm{Mg}$ as they are both affected by this process (Fig. 4).

\section{Other phenomena associated with seasonal dryness}

A more radical pattern is the complete cessation of seasonal dripping. This could give rise to microhiatuses (Treble et al., 2005b), and complex re-growth phenomena. Seasonal changes in mineralogy from calcite to aragonite (Railsback et al. 1994) imply strong reductions in driprate and prior calcite precipitation. More generally, where drip rates are slow, it is more likely that the cave air is at less than $100 \%$ humidity, and evaporation effects on both $\delta^{13} \mathrm{C}$ and $\delta^{18} \mathrm{O}$ are to 




Fig. 4. Modelling of the effects of prior calcite precipitation on $\mathrm{Sr}$ and Mg, based on a study in Clamouse Cave, S. France (McMillan et al., 2005). Inset (top left) shows effect of progressive removal of $\mathrm{Ca}$ (vertical axis is the same as the main chart), leading to enrichments in $\mathrm{Sr}$ and $\mathrm{Mg}$ in the calcite compared with the baseline conditions. The enrichments depend on their partition coefficient, here modelled as 0.035 for $\mathrm{Mg}$ and 0.15 for Sr. The main plot shows the variations with distance of prior calcite precipitation in stalagmite CL26. The arid interval corresponds to the period 750-850 A.D. and is unprecedented in the last $3 \mathrm{ka}$ of the speleothem record. Inset (top right) shows data within the calcite interval displaying annual variations in $\mathrm{Sr}$ and $\mathrm{Mg}$.

be expected, leading to covariations along stalagmite laminae (Hendy, 1971).

\section{INSIGHTS FROM HIGH-RESOLUTION METHODS}

Long-term covariations in proxies such as $\delta^{13} \mathrm{C}$, $\mathrm{Mg}$ and $\mathrm{Sr}$ could reflect variations in palaeo-aridity, but it is advantageous to have knowledge of seasonal variations so that the processes underlying a longerterm trend can be understood. Oxygen isotope data are now being generated on a sub-annual scale (Treble et al., 2005c) which allows summer and winter precipitation to be distinguished. Although many drips have homogenized compositions (Williams et al., 2004), the presence of a fracture-fed component allows the seasonal variation to be distinguished (Fairchild et al., 2006b). High-resolution trace element data can be generated by a variety of techniques and annual variations are normally found. Technical issues underlying the generation of sub-annual chemistries are dealt with by Fairchild et al. (2006b).

Figure 4 illustrates a case example where the seasonal controls are well-understood and hence the long-term changes can be interpreted with confidence. Two stalagmites from the Clamouse cave in southern France both display an aragonite layer dated at around 1100 years BP, and are preceded by a period of Mg-enrichment in calcite that was unmatched in the last $3 \mathrm{ka}$ (McMillan et al., 2005). High resolution analyses (Fig. 4, right inset) show distinct covariations with a spatial interval consistent both with annual growth rates (McMillan et al., 2005) and the seasonal drying and accentuated prior calcite precipitation inferred from cave monitoring (Fairchild et al., 2000). The expected enrichment in $\mathrm{Sr}$ and $\mathrm{Mg}$ from prior calcite precipitation can be modelled (Fig. 4 , left inset) - the slightly larger amplitude of variation of $\mathrm{Sr}$ compared with $\mathrm{Mg}$ observed in the data can be 
attributed to kinetic effects. Hence the seasonal and long-term variation in prior calcite precipitation can be calculated (fig. 4) and was used by McMillan et al. (2005) as a proxy for palaeoaridity. The inferred 100-year period of below-normal filling of the aquifer appears to represent an arid period of widespread geographic extent (Jalut et al. 2000; Street-Perrott et al. 2000; Haug et al. 2003) .

Distinction of local temporal variations in aquifer plumbing from genuine climatic effects is important. A reversal of a trend is consistent with a climatic process, whereas changes in plumbing might be irreversible. Growth hiatuses related to climatic events might be expected to show a gradual shift in chemistries and/ or growth rates before and after the central event. All these topics are the subject of ongoing research.

\section{ACKNOWLEDGEMENTS}

Thanks to a wide variety of colleagues, and in particular Dr. Bartolomé Andreo and colleagues at the University of Málaga, for encouragement and advice. Our recent work has been supported by a grant from the UK's Natural Environment Research Council in the Rapid Climate Change programme and a $\mathrm{PhD}$ studentship to EMM from Keele University.

\section{REFERENCES}

Ayalon A., Bar-Matthews M. \& Sass E., 1998 - Rainfallrecharge relationships within a karstic terrain in the Eastern Mediterranean semi-arid region, Israel: $\delta^{18} \mathrm{O}$ and $\delta D$ characteristic: J. Hydrol., 207: 18-31.

Baker A., Genty D. \& Fairchild I.J., 2000 - Hydrological characterisation of stalagmite drip waters at Grotte de Villars, Dordogne, by the analysis of inorganic species and luminescent organic matter. Hydrology and Earth System Sciences, 4: 439-449.

Bar-Matthews M., Ayalon A., Gilmour M., Matthews A. \& Hawkesworth C.J., 2003 - Sea-land oxygen isotopic relationships from planktonic foraminifera and speleothems in the Eastern Mediterranean region and their implication for paleorainfall during interglacial intervals. Geochim. Cosmochim. Acta, 67: 3181-3199.

Bourges, F., Genthon, P., Mangin, A., \& d'Hulst, D. 2006 - Microclimates of L'Aven d'Orgnac and other French limestone caves (Chauvet, Esparros, Marsoulas)/ Int. J. Climatology, 26: 1651-1670.

Bourges, F., Mangin, A., \& d'Hulst, D. 2001 - Carbon dioxide in karst cavity atmosphere dynamics: the example of the Aven d'Orgnac (Ardeche). Comptes Rendus De L Academie Des Sciences Serie Ii Fascicule a-Sciences De La Terre Et Des Planetes 333: 685-692.

Dreybrodt W., 1988 - Processes in karst systems. Springer-Verlag, Berlin.

Dreybrodt W., 1999 - Chemical kinetics, speleothem growth and climate. Boreas, 28: 347-356.

Fairchild I.J., Borsato A., Tooth A.F., Frisia S., Hawkesworth C.J., Huang Y., McDermott F. \& Spiro B., 2000 - Controls on trace element (Sr-Mg) compositions of carbonate cave waters: implications for speleothem climatic records. Chem. Geol., 166: 255-269.
Fairchild I.J., Tuckwell G.W., Baker A. \& Tooth A.F., 2006a - Modelling of dripwater hydrology and hydrogeochemistry in a weakly karstified aquifer (Bath, UK): implications for climate change studies. J. Hydrol., 321, 213-231.

Fairchild I.J., Smith C.L., Baker A., Fuller L., Spötl C., Mattey D., McDermott F. \& E.I.M.F., 2006b Modification and preservation of environmental signals in speleothems. Earth-Sci. Rev., 75: 105-153.

Fairchild I.J., Frisia S., Borsato A. \& Tooth A.F., 2007 - Speleothems in their geomorphic, hydrological and climatological context. In: Nash, D.J \&, McLaren, S.J. (Eds), Geochemical Sediments and Landscapes. Oxford: Blackwell, in press.

Fleitmann D., Burns S.J. \& Mudelsee M.., 2003 - Holocene forcing of the Indian monsoon recorded in a stalagmite from Southern Oman. Science, 300: 1737-1739.

Fleitmann D., Burns S.J., Mangini, A., Mudelsee, M., Kramers, J., Villa, I., Neff, U., Al-Subbary, A.A., Buettner, A., Hippler, D.\& Matter, A., 2003 - Holocene ITCZ and Indian monsoon dynamics recorded in stalagmites from Oman and Yemen (Socotra) Quat. Sci. Rev., 26: 170-188.

Genty, D. \& Deflandre, G., 1998 - Drip flow variations under a stalactite of the Père-Nöel Cave (Belgium). Evidence of seasonal variations and air pressure constraints. J. Hydrology, 211, 208-232.

Genty D., Baker A. \& Vokal B., 2001 - Intra- and interannual growth rate of modern stalagmites. Chem. Geol., 176, 191-212.

Haug G.H., Günther D., Peterson L.C., Sigman D.M., Hughen K.A. \& Aeschilmann B. 2003 - Climate and the collapse of the Maya Civilisation. Science, 299: 17311735

Hendy C.H., 1971 - The isotopic geochemistry of speleothems - I. The calculation of the effects of different modes of formation on the isotopic composition of speleothems and their applicability as palaeoclimatic indicators. Geochim. Cosmochim. Acta, 35: 801-824.

Hoyos, M., Soler, V., Cañavera, J.C., Sánchez-Moral, S. \& Sanz-Rubio, E. 1998 - Microclimatic characterization of a karstic cave: human impact on microenvironmental parameters of a prehistoric rock art cave (Candamo Cave, northern Spain). Environmental Geology, 33, 231-242.

Jalut G., Amat A.E., Bonnet L., Gauquelin T. \& Fontugne M. 2000 - Holocene climatic changes in the Western Mediterranean from south-east France to south-east Spain. Palaeogeography, Palaeoclimatology, Palaeoecology, 160: 255-290

Johnson K.R., Hu C., Belshaw N.S. \& Henderson G.M., 2006 - Seasonal trace-element and stable isotope variations in a Chinese speleothem: The potential for high-resolution paleomonsoon reconstruction. Earth Planet. Sci. Lett., 244: 394-407.

Mangin A., 1975. Contribution à l'étude des aquifères karstiques. Annales de Spéléologie, 29, 283-332 \& 495-601; 30, 21-124.

Mangini A., Spötl C. \& Verdes P., 2005 - Reconstruction of temperature in the Central Alps during the past 2000 yr from a $\delta^{18} \mathrm{O}$ stalagmite record. Earth Planet. Sci. Lett., 235: 741-751. 
McDermott F., Frisia S., Huang Y., Longinelli A., Spiro B., Heaton T.H.E., Hawkesworth C.J., Borsato A., Keppens E., Fairchild I.J., van der Borg K., Verheyden S. \& Selmo E., 1999 - Holocene climate variability in Europe: evidence from $\delta^{18} \mathrm{O}$ and textural variations in speleothems. Quat. Sci. Rev., 18: 1021-1038.

McDermott F., Schwarcz H.P. \& Rowe, P.J., 2005 - 6. Isotopes in speleothems. In: Leng, M.J. (Ed.) Isotopes in Palaeoenvironmental Research. Springer, Dordrecht, The Netherlands, (in press).

McMillan E.A, Fairchild I.J., Frisia S., Borsato A. \& McDermott F., 2005 - Annual trace element cycles in calcite-aragonite speleothems: evidence of drought in the western Mediterranean 1200-1100 yr BP. J. Quat. Sci., 20: 423-433.

Railsback LB., Brook G.A., Chen J., Kalin R., Fleisher C.J., 1994 - Environmental controls on the petrology of a late Holocene speleothem from Botswana with annual layers of aragonite and calcite. J. Sediment. Res., A64: 147-155

Spötl C., Fairchild I.J. and Tooth A.F., 2005 - Cave air control on dripwater geochemistry, Obir Caves (Austria): Implications for speleothem deposition in dynamically ventilated caves. Geochim. Cosmochim. Acta, 69: 2451-2468.

Street-Perrott F.A., Holmes J.A., Waller M.P., Allen M.J., Barber N.G.H., Fothergill P.A., Harkness D.D., Ivanovich M., Kroon D., \& Perrott R.A. 2000 - Drought and dust deposition in the West African Sahel: a 5500year record from Kajemarun Oasis, northeastern Nigeria. Holocene, 10: 293-302
Tooth A.F. \& Fairchild I.J. 2003 - Soil and karst aquifer hydrological controls on the geochemical evolution of speleothem-forming drip waters, Crag Cave, southwest Ireland. J. Hydrol., 273: 51-68.

Treble P., Budd W.F., Hope P.K. \& Rustomji P.K. 2005a - Synoptic-scale climate patterns associated with rainfall delta $O-18$ in southern Australia. J. Hydrol., 302: 270-282.

Treble P., Chappell J., Gagan M.K., McKeegan K.D. and Harrison T.M., 2005b - In situ measurement of seasonal $\delta^{18} \mathrm{O}$ variations and isotopic trends in a modern speleothem from southwest Australia. Earth Planet. Sci. Lett., 233: 17-32.

Treble P.C., Chappell J. \& Shelley J.M.G. 2005c Complex speleothem growth processes revealed by trace element mapping and scanning electron microscopy of annual layers. Geochim. Cosmochim. Acta, 69: 4855-4864.

Wang Y., Cheng H., Edwards R.L., He Y., Kong X., An Z., Wu J., Kelly M.J., Dykoski C.A. \& Li X., 2005 - The Holocene Asian Monsoon: links to solar changes and North Atlantic climate. Science, 308: 854-857.

Williams, P.W., King, D.N.T., Zhao, J.-X. \& Collerson, K.D., 2004. Speleothem master chronologies: combined Holocene ${ }^{18} \mathrm{O}$ and ${ }^{13} \mathrm{C}$ records from the North Island of New Zealand and their palaeoenvironmental interpretation. Holocene 14: 194-208. 